\title{
CO Hydrogenation Catalyzed by Alumina-Supported Osmium: Particle Size Effects
}

\author{
E. O. Odebunmi, ${ }^{*, 2}$ B. A. Matrana ${ }^{* 3}$ A. K. Datye, $\dagger$ L. F. Allard, JR. $\ddagger$ \\ J. Schwank, $\uparrow$ W. H. Manogue, $\S$ A. Hayman, $\$$ J. H. Onuferko, ${ }^{*, 4}$ \\ H. KNÖZINGER, \| AND B. C. GATES ${ }^{*, 1}$ \\ *Center for Catalytic Science and Technology, Department of Chemical Engineering, University of \\ Delaware, Newark, Delaware 19716; Departments of $\dagger$ Chemical Engineering and $\$$ Materials and \\ Metallurgical Engineering, University of Michigan, Ann Arbor, Michigan 48109; $E$. I. du Pont de Nemours \\ and Company, Experimental Station, Wilmington, Delaware 19898; and |Institut für Physikalische Chemie, \\ Universität München, Sophienstrasse 11, 8000 Munich, 2, West Germany
}

Received October 20, 1984; revised April 24, 1985

\begin{abstract}
Alumina-supported catalysts were prepared by conventional aqueous impregnation with $\left[\mathrm{H}_{2} \mathrm{OsCl}_{6}\right]$ and by reaction of organoosmium clusters $\left\{\left[\mathrm{Os}_{3}(\mathrm{CO})_{12}\right],\left[\mathrm{H}_{4} \mathrm{Os}_{4}(\mathrm{CO})_{12}\right]\right.$, and $\left.\left[\mathrm{Os}_{6}(\mathrm{CO})_{18}\right]\right\}$ with the support. The catalysts were tested for $\mathrm{CO}$ hydrogenation at $250-325^{\circ} \mathrm{C}$ and $10 \mathrm{~atm}$, the products being Schulz-Flory distributions of hydrocarbons with small yields of dimethyl ether. The fresh and used catalysts were characterized by infrared spectroscopy and high-resolution transmission electron microscopy. The catalyst prepared from $\left[\mathrm{H}_{2} \mathrm{OsCl}_{6}\right]$ had larger particles of $\mathrm{Os}(\sim 70 \AA)$. The cluster-derived catalysts initially consisted of molecular clusters on the support; the used catalysts contained small Os aggregates (typically 10-20 $\AA$ in diameter). The catalytic activity for hydrocarbon formation increased with increasing Os aggregate size, but the activity for dimethyl ether formation was almost independent of aggregate size. The hydrocarbon synthesis was evidently catalyzed by the Os aggregates, and the ether synthesis was perhaps catalyzed by mononuclear Os complexes. $\bigcirc 1985$ Academic Press, Inc.
\end{abstract}

\section{INTRODUCTION}

Supported osmium catalysts prepared from cluster carbonyls have been investigated in detail because many appear to have simple structures, some with relatively high stabilities (1-7). For example, mononuclear Os(II) carbonyl complexes were observed to be the predominant metal species on $\mathrm{Al}_{2} \mathrm{O}_{3}$ after $\mathrm{CO}$ hydrogenation at atmospheric pressure (2); under more severe reaction conditions, however, small Os metal particles were observed on $\mathrm{Al}_{2} \mathrm{O}_{3}$ supported catalysts prepared from some of the same precursors, e.g., $\left[\mathrm{Os}_{3}(\mathrm{CO})_{12}\right](I)$. The range of accessible structures of sup-

${ }^{1}$ To whom correspondence should be addressed.

2 Present address: Chemistry Department, University of Ilorin, Ilorin, Nigeria.

${ }^{3}$ Present address: Goodyear Research Laboratory, Akron, Ohio 44316.

${ }^{4}$ Present address: W. R. Grace and Company, Research Division, Columbia, Md. 21044. ported Os motivated us to prepare a series of these catalysts to determine relations between structure and catalytic activity and selectivity for $\mathrm{CO}$ hydrogenation.

One specific goal was to prepare very small aggregates of Os on oxide supports and to determine the dependence of catalytic activity on aggregate size. Catalysts were prepared from tri-, tetra-, and hexanuclear osmium carbonyls supported on $\gamma$ $\mathrm{Al}_{2} \mathrm{O}_{3}$. For comparison, Os catalysts were also prepared by the conventional route of impregnation of the support with aqueous chloroosmic acid, followed by calcining and reduction. $\mathrm{MgO}$ and $\mathrm{TiO}_{2}$ were used briefly in addition to $\gamma-\mathrm{Al}_{2} \mathrm{O}_{3}$ to provide a measure of support effects.

\section{EXPERIMENTAL}

\section{Catalyst Preparation}

Osmium catalysts supported on $\gamma-\mathrm{Al}_{2} \mathrm{O}_{3}$ (Conoco Catapal, $240 \mathrm{~m}^{2} / \mathrm{g}$ ) were prepared 
TABLE 1

Supported Osmium Catalysts Used for CO Hydrogenation

\begin{tabular}{|c|c|c|c|c|}
\hline Catalyst precursor/support & $\begin{array}{l}\text { Os content } \\
(w t \%)\end{array}$ & $\mathrm{H} / \mathrm{Os}^{\mathrm{a}}$ & $\mathrm{CO} / \mathrm{Os}^{a}$ & Catalyst pretreatment/reaction conditions $s^{b}$ \\
\hline$\left[\mathrm{Os}_{6}(\mathrm{CO})_{18}\right] / \mathrm{Al}_{2} \mathrm{O}_{3}$ & 1.30 & & & $\begin{array}{l}1 \mathrm{~h} \text { in } \mathrm{He} \text { at } 150^{\circ} \mathrm{C}, \mathrm{I} \mathrm{h} \text { in } \mathrm{H}_{2} \text { at } 275^{\circ} \mathrm{C} / \\
250-300^{\circ} \mathrm{C}\end{array}$ \\
\hline$\left[\mathrm{H}_{4} \mathrm{Os}_{4}(\mathrm{CO})_{12}\right] / \mathrm{Al}_{2} \mathrm{O}_{3}$ & 1.03 & & & $\begin{array}{l}1 \mathrm{~h} \text { in } \mathrm{He} \text { at } 150^{\circ} \mathrm{C}, 1 \mathrm{~h} \text { in } \mathrm{H}_{2} \text { at } 275^{\circ} \mathrm{C} / \\
275^{\circ} \mathrm{C}\end{array}$ \\
\hline$\left[\mathrm{Os}_{3}(\mathrm{CO})_{12}\right] / \mathrm{Al}_{2} \mathrm{O}_{3}$ & 1.68 & & & As above \\
\hline$\left[\mathrm{Os}(\mathrm{CO})_{5}\right] / \mathrm{Al}_{2} \mathrm{O}_{3}^{\mathrm{c}}$ & 0.36 & & & As above \\
\hline$\left[\mathrm{Os}(\mathrm{CO})_{3}\right] / \mathrm{Al}_{2} \mathrm{O}_{3}{ }^{\mathrm{c}}$ & 0.36 & & & $\begin{array}{l}1 \mathrm{~h} \text { in } \mathrm{He} \text { at } 150^{\circ} \mathrm{C},>10 \mathrm{~h} \text { in } \mathrm{H}_{2} \text { at } 275^{\circ} \mathrm{C} / \\
250-325^{\circ} \mathrm{C}\end{array}$ \\
\hline$\left[\mathrm{H}_{2} \mathrm{OsCl}_{6}\right] / \mathrm{Al}_{2} \mathrm{O}_{3}$ & 5 & 0.30 & 0.24 & $\begin{array}{l}1 \mathrm{~h} \text { in } \mathrm{He} \text { at } 150^{\circ} \mathrm{C},>10 \mathrm{~h} \text { in } \mathrm{H}_{2} \text { at } 275^{\circ} \mathrm{C} / \\
250-325^{\circ} \mathrm{C}\end{array}$ \\
\hline$\left[\mathrm{H}_{2} \mathrm{OsCl}_{6}\right] / \mathrm{TiO}_{2}$ & 5 & 0.13 & 0.28 & As above $/ 250-300^{\circ} \mathrm{C}$ \\
\hline$\left[\mathrm{H}_{2} \mathrm{OsCl}_{6}\right] / \mathrm{MgO}$ & 5 & 0.11 & 0.12 & As above $/ 250-325^{\circ} \mathrm{C}$ \\
\hline
\end{tabular}

a Calculated from volume of $\mathrm{H}_{2}$ or $\mathrm{CO}$ adsorbed at $25^{\circ} \mathrm{C}$, extrapolated to zero pressure.

b Other reaction conditions: pressure $=10 \mathrm{~atm}, \mathrm{H}_{2} / \mathrm{CO}$ molar ratio $=1,2$, or 3 .

$c$ Ref. (9).

from $\left[\mathrm{Os}_{3}(\mathrm{CO})_{12}\right]$ (Strem), $\left[\mathrm{H}_{4} \mathrm{Os}_{4}(\mathrm{CO})_{12}\right]$, and $\left[\mathrm{Os}_{6}(\mathrm{CO})_{18}\right]$ by refluxing a solution of each cluster in $n$-octane with the support, as described previously (2). Catalysts were analyzed for Os by Schwarzkopf Microanalytical Laboratory, Woodside, N.Y.

Catalysts were also prepared from $\left[\mathrm{H}_{2} \mathrm{OsCl}_{6} \cdot 6 \mathrm{H}_{2} \mathrm{O}\right]$ (Colonial Metals) by aqueous impregnation. The appropriate mass of $\left[\mathrm{H}_{2} \mathrm{OsCl}_{6}\right]$ was dissolved in just enough deionized water to ensure complete wetting of the support. The solution was mixed with each of the supports $\left[\gamma-\mathrm{Al}_{2} \mathrm{O}_{3}, \mathrm{MgO}\right.$ (MCB, $\mathrm{MX} 65,51 \mathrm{~m}^{2} / \mathrm{g}$ ), and $\mathrm{TiO}_{2}$ (anatase, $53 \mathrm{~m}^{2 /}$ g)] to form a paste, which was dried at $110^{\circ} \mathrm{C}$ under $\mathrm{N}_{2}$. The dried catalyst was ground into a fine powder. Each sample was reduced in flowing $\mathrm{H}_{2}$ in the reactor prior to a catalytic reaction experiment.

A list of the catalysts and their Os contents is given in Table 1.

\section{Catalytic Hydrogenation of $\mathrm{CO}$}

The catalytic reaction experiments were carried out with a flow reactor system, described elsewhere (8). The microreactor was a copper-lined tube connected by a heated exit line to a gas chromatograph.
Catalyst pretreatment in the reactor preceded all the $\mathrm{CO}$ hydrogenation experiments. For the cluster-derived catalysts, this pretreatment involved bringing the reactor to pressure $(10 \mathrm{~atm})$ with $\mathrm{He}$, heating in flowing $\mathrm{He}$ to $150^{\circ} \mathrm{C}$, and holding for $1 \mathrm{~h}$. The temperature was then gradually raised to $275^{\circ} \mathrm{C}$ with flowing $\mathrm{He}$, and then $\mathrm{H}_{2}$ flow at $10 \mathrm{~cm}^{3} / \mathrm{min}$ was started and He flow was cut off. The catalyst was held in flowing $\mathrm{H}_{2}$ at $275^{\circ} \mathrm{C}$ for $1 \mathrm{~h}$, and then the flow of $\mathrm{CO}$ was started.

The supported Os catalysts prepared from $\left[\mathrm{H}_{2} \mathrm{OsCl}_{6}\right]$, after initial treatment in $\mathrm{He}$ at $150^{\circ} \mathrm{C}$ for $1 \mathrm{~h}$, were typically reduced in flowing $\mathrm{H}_{2}\left(10 \mathrm{~cm}^{3} / \mathrm{min}\right)$ at $275^{\circ} \mathrm{C}$ for $>10 \mathrm{~h}$. The longer time of reduction was necessary to ensure that the Os was completely reduced to the zerovalent state and to reduce the amount of residual chlorine in the catalyst. One of the $\mathrm{TiO}_{2}$-supported samples was reduced in flowing $\mathrm{H}_{2}$ at $275^{\circ} \mathrm{C}$ and another was reduced at $350^{\circ} \mathrm{C}\left(50^{\circ} \mathrm{C}\right.$ higher than the maximum temperature in the catalytic reaction experiments) to determine whether a more severe reduction would influence the catalyst performance.

The reaction of $\mathrm{CO}+\mathrm{H}_{2}$ was investi- 
gated at $250-325^{\circ} \mathrm{C}$ and $10 \mathrm{~atm}$, with various reactant compositions and flow rates. During a catalysis experiment the reactor temperature, pressure, and feed-gas flow rates were held constant, and the product stream was analyzed periodically. The analysis was performed with an Antek 300 gas chromatograph equipped with a flame ionization detector. Temperature programming of the column involved an initial $1-\mathrm{min}$ hold at $65^{\circ} \mathrm{C}$, heating at $20^{\circ} \mathrm{C} / \mathrm{min}$ to $180^{\circ} \mathrm{C}$, and then a $15-\mathrm{min}$ hold at $180^{\circ} \mathrm{C}$. This procedure ensured good hydrocarbon separation in a $\frac{1}{8}$-in $\times 6$-ft stainless-steel column packed with activated alumina and good oxygenate separation in a similar column packed with SE-30 (Supelco, Inc.).

The few catalytic reaction experiments were done with a glass batch reactor, with the products followed as a function of time with a mass spectrometer.

\section{High-Resolution Electron Microscopy}

For high-resolution transmission electron microscopy, samples of cluster-derived $\mathrm{Al}_{2} \mathrm{O}_{3}$-supported catalysts (after treatment in $\mathrm{He}$ at $200^{\circ} \mathrm{C}$ and after catalysis) were placed on 2.3-mm copper grids, which had been cleaned in dilute $\mathrm{HCl}$, rinsed in distilled water, immersed in chloroform, and dried. The grids were dipped into the catalyst powder and shaken so that only minute amounts of the catalyst adhered to the grids.

The micrographs were obtained with a JEOL JEM-100 CX transmission electron microscope equipped with an ultrahigh-resolution pole piece, a top-entry stage, and a $\mathrm{LaB}_{6}$ emitter operated at $100 \mathrm{keV}$. The magnification was calibrated with the lattice fringes of partially graphitized carbon (3.4 $\AA$ ). Only areas projecting away from the copper grid were examined. Since $\mathrm{Al}_{2} \mathrm{O}_{3}$ contributes considerable contrast in the thick regions, only the thinnest regions at the edges of the $\mathrm{Al}_{2} \mathrm{O}_{3}$ particles could be examined in high resolution.

The fine structure of $\gamma-\mathrm{Al}_{2} \mathrm{O}_{3}$ was used as a guide to determine the optimum defocus
(6); only limited areas within the field of view were in the optimum defocus (Scherzer) position. Images were recorded at a nominal magnification of 550,000 . The exact magnification was computed from the magnification calibration curve as a function of objective lens current.

Since the high-resolution microscopy was restricted to the outer edges of the samples where the $\gamma-\mathrm{Al}_{2} \mathrm{O}_{3}$ was thinnest, it was necessary to use complementary techniques to characterize the thicker regions of the support-in particular, to check for possible agglomeration of Os into larger particles. Metal particles are detectable when they provide sufficient contrast; where the support was too thick and the contrast insufficient, it was advantageous to use scanning transmission electron microscopy, since both the contrast and brightness of the image can be varied electronically, making it easier to distinguish between the support and metal particles. It was also possible to perform elemental analyses of dark regions where the presence of large metal particles $(>10 \AA$ in diameter) was suspected. The JEOL JEM100 CX microscope, operated with a side-entry goniometer stage, allowed scanning transmission electron microscopy with the EM-ASID-4D scanning system. Elemental analyses (for atomic numbers between 11 and 84) were performed with a lithium-drifted solid-state X-ray detector (Princeton $\gamma$-Tech) coupled to a Nuclear Data 6620 computer.

For the side-entry stage work, the samples were placed on holey carbon films supported on copper grids according to a procedure described previously (6). The grids were placed into a graphite insert designed to give better X-ray counting statistics than can be obtained with the standard JEOL copper-alloy specimen holder.

The technique for identifying metal particles involved rastering the electron beam over an area approximately $250 \times 250 \AA$ for $100 \mathrm{~s}$. The beam was then allowed to rest for another $100 \mathrm{~s}$ in point mode on dark 
regions suspected of being metal crystallites. If the Os concentration determined in the point mode was substantially higher than that determined in the raster mode, the result was interpreted as confirmation of the presence of Os in the dark region in question. To achieve adequate X-ray counting statistics, an electron beam approximately $100 \AA$ in diameter was used. Smaller beams did not yield a sufficient $X$ ray signal with the tungsten filament used as an electron source for the side-entry work.

Samples of used catalysts prepared from $\left[\mathrm{H}_{2} \mathrm{OsCl}_{6}\right]$ were characterized with a Philips EM-400T microscope, which did not provide the high resolution required with the other samples. The sample preparation methods were similar to those described above.

\section{Chemisorption of $\mathrm{H}_{2}$ and $\mathrm{CO}$}

Gas uptake was measured with a Micromeritics Model 2180D analyzer in the static pressure mode. Hydrogen was purified by passage through a Deoxo catalytic converter and $4 \mathrm{~A}$ molecular sieve trap. Carbon monoxide was purified by passage through activated carbon at $150^{\circ} \mathrm{C}$. UHP helium was used as received. Samples were reduced in $760 \mathrm{Torr}$ of hydrogen at $275^{\circ} \mathrm{C}$ for $4 \mathrm{~h}$ followed by evacuation at $10^{-5}$ Torr and $257^{\circ} \mathrm{C}$ for $12 \mathrm{~h}$ prior to gas uptake measurements. Hydrogen dosing pressures were 75 , $125,170,225$, and 275 Torr. Catalysts were rereduced prior to $\mathrm{CO}$ measurement with the same dosing pressures.

\section{Infrared Spectroscopy}

Wafers of the catalysts were characterized with a Nicolet 7199 Fourier transform infrared spectrophotometer. The cell was quartz with $\mathrm{NaCl}$ windows and a quartz sample holder. It was connected to a flow system (7) providing the capability for treatment of samples under vacuum or in various gas atmospheres.

Infrared spectra of both fresh and used catalysts were recorded. Experiments with the former in the presence of $\mathrm{CO}+\mathrm{H}_{2}$ provided evidence of the changes in structure under the conditions of pretreatment in the catalytic reactor, except that the pressure was $1 \mathrm{~atm}$ in the infrared cell, whereas it was $10 \mathrm{~atm}$ in the flow reactor. In a typical infrared experiment, a fresh sample was flushed with $\mathrm{He}$ at room temperature before its spectrum was recorded. The temperature was then gradually raised to $150^{\circ} \mathrm{C}$, and the spectrum was recorded after about 1-h exposure to flowing $\mathrm{He}$. As the temperature was raised further, spectra were recorded at $275^{\circ} \mathrm{C}$ with the sample in $\mathrm{He}$, at $275^{\circ} \mathrm{C}$ after 1-h exposure to flowing $\mathrm{H}_{2}$, and at $275^{\circ} \mathrm{C}$ after treatment with an equimolar $\mathrm{CO}$ $+\mathrm{H}_{2}$ mixture. A similar sequence of experiments was carried out to determine the spectra of the used catalyst samples.

\section{RESULTS}

\section{Performance of Catalysts Prepared from $\left[\mathrm{H}_{2} \mathrm{OsCl}_{6}\right]$}

The hydrogenation of $\mathrm{CO}$ catalyzed by supported Os prepared by aqueous impregnation yielded predominantly hydrocarbons; oxygenated products were observed in only trace amounts. The results obtained with the $\mathrm{Al}_{2} \mathrm{O}_{3^{-}}, \mathrm{MgO}-$, and $\mathrm{TiO}_{2}$-supported catalysts are summarized in Tables 2 and 3 and Figs. 1-4. All the catalysts had initially high activities, which decreased with time on stream (Fig. 1). (Zero time on stream is defined as the beginning of $\mathrm{CO}$ flow.) In each case, a stable (steady-state) activity was observed after about $20 \mathrm{~h}$ on stream. The effect of space velocity on the steadystate conversion was determined with the $\mathrm{Al}_{2} \mathrm{O}_{3}$-supported catalyst; the conversion to hydrocarbons was proportional to the inverse space velocity, which demonstrates that the conversions $<7 \%$ were differential, determining reaction rates directly. (All the values of rates presented here were calculated from differential conversions.) The selectivity to methane was independent of space velocity with this catalyst.

The effect of the support on the catalytic 


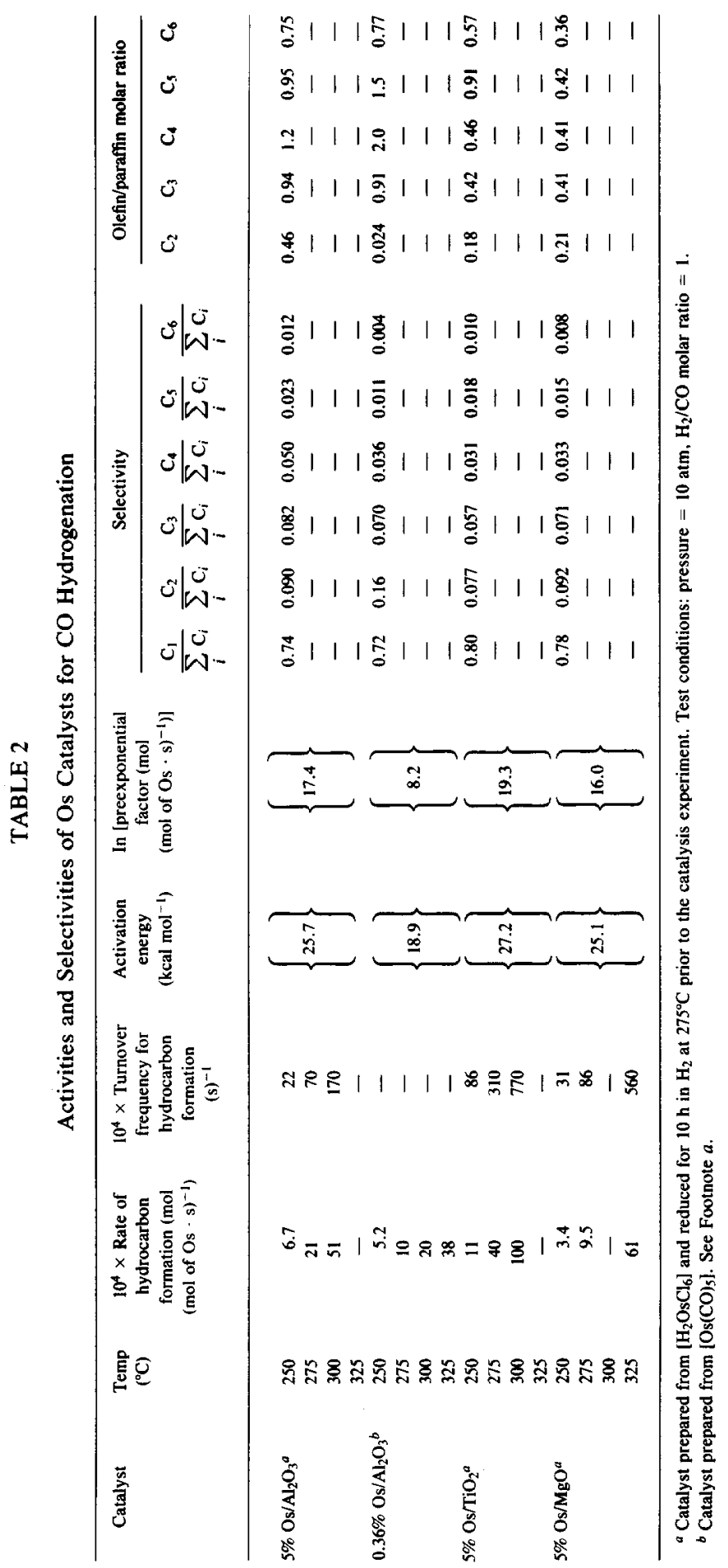


TABLE 3

Product Distribution in CO Hydrogenation Catalyzed by 5 wt\% Os $/ \mathrm{Al}_{2} \mathrm{O}_{3}$ Prepared from $\left[\mathrm{H}_{2} \mathrm{OsCl}_{6}\right]$

\begin{tabular}{|c|c|c|c|c|c|c|c|c|c|c|c|c|c|}
\hline \multirow{3}{*}{$\begin{array}{l}\text { Temp. } \\
\left({ }^{\circ} \mathrm{C}\right)\end{array}$} & \multirow{3}{*}{$\begin{array}{c}\mathrm{H}_{2} / \mathrm{CO} \\
\text { molar } \\
\text { ratio }\end{array}$} & \multicolumn{7}{|c|}{ Selectivity } & \multicolumn{5}{|c|}{ Olefin/parafinn molar ratio } \\
\hline & & $c_{1}$ & $\mathrm{C}_{2}$ & $\mathrm{C}_{3}$ & $\mathrm{C}_{4}$ & $\mathbf{C}_{5}$ & $\mathrm{C}_{6}$ & $\mathbf{C}_{7}$ & $\mathbf{C}_{2}$ & $\mathrm{C}_{3}$ & $\mathbf{C}_{4}$ & $c_{5}$ & $\mathrm{C}_{6}$ \\
\hline & & $\sum_{i} c_{i}$ & $\sum_{i} c_{i}$ & $\sum_{i} c_{i}$ & $\sum_{i} c_{i}$ & $\sum_{i} c_{i}$ & $\sum_{i} c_{i}$ & $\sum_{i} c_{i}$ & & & & & \\
\hline 250 & 1 & 0.74 & 0.090 & 0.082 & 0.050 & 0.023 & 0.012 & 0.005 & 0.46 & 0.94 & 1.2 & 0.95 & 0.75 \\
\hline \multirow[t]{3}{*}{275} & 1 & 0.77 & 0.080 & 0.070 & 0.043 & 0.023 & 0.013 & 0.004 & 0.45 & 1.2 & 1.3 & 1.1 & 1.2 \\
\hline & 2 & 0.81 & 0.078 & 0.053 & 0.030 & 0.016 & 0.009 & 0.003 & 0.31 & 0.94 & 0.86 & 0.75 & 0.71 \\
\hline & 3 & 0.84 & 0.072 & 0.049 & 0.024 & 0.011 & 0.006 & 0.002 & 0.22 & 0.85 & 0.77 & 0.69 & 0.58 \\
\hline 285 & 1 & 0.79 & 0.078 & 0.067 & $\mathbf{0 . 0 3 6}$ & 0.019 & 0.011 & 0.003 & 0.39 & 1.3 & 1.1 & 0.97 & 1.0 \\
\hline 310 & 1 & 0.82 & 0.065 & 0.053 & 0.028 & 0.016 & 0.010 & 0.003 & 0.19 & 1.3 & 1.1 & 1.0 & 1.0 \\
\hline
\end{tabular}

${ }^{a}$ Pressure $=10 \mathrm{~atm}$.

activity is shown by the data of Table 2 . The catalyst supported on $\mathrm{MgO}$ was the least active and that supported on $\mathrm{TiO}_{2}$ the most active. The $\mathrm{MgO}$-supported catalyst initially had a low activity, which increased over the first $80 \mathrm{~h}$ on stream. After the catalyst had been reactivated by reduction in flowing $\mathrm{H}_{2}$ at $275^{\circ} \mathrm{C}$ for $\sim 6 \mathrm{~h}$, changes in the activity with time on stream followed the same pattern observed with the other supports (Fig. 1). The temperature of reduction did not have a significant effect on the activity of the $\mathrm{TiO}_{2}$-supported catalyst. At

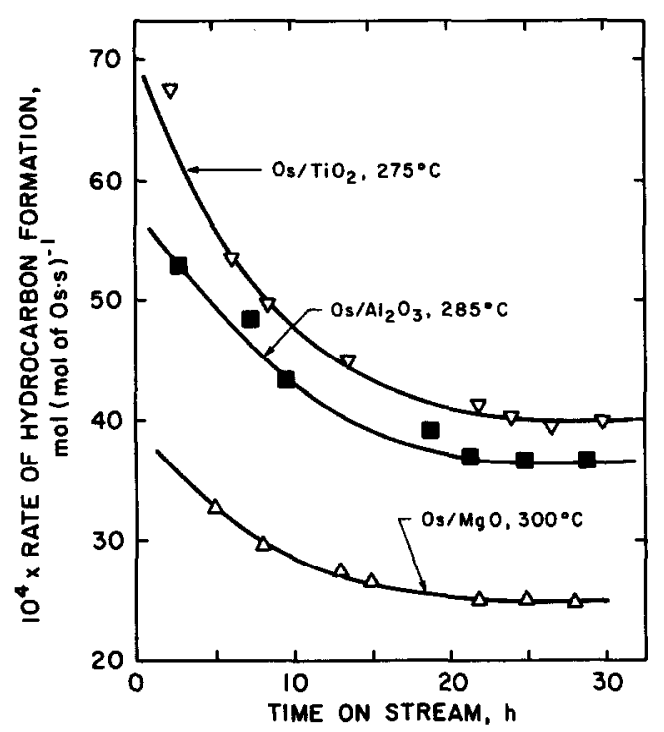

Fig. 1. Hydrocarbon formation from $\mathrm{CO}+\mathrm{H}_{2}$ in the presence of catalysts from $\left[\mathrm{H}_{2} \mathrm{OsCl}_{6}\right]$. each reaction temperature $\left(250\right.$ or $\left.275^{\circ} \mathrm{C}\right)$, nearly the same reaction rates were measured for the catalysts reduced at 275 and at $350^{\circ} \mathrm{C}$.

The reaction rates increased with temperature in the Arrhenius fashion (Fig. 2). The apparent activation energies were calculated to be $25.1,25.7$, and $27.2 \mathrm{kcal} / \mathrm{mol}$ for the Os supported on $\mathrm{MgO}, \mathrm{Al}_{2} \mathrm{O}_{3}$, and $\mathrm{TiO}_{2}$, respectively. The preexponential factors are given in Table 2. Data for comparison are shown in Fig. 2 for an $\mathrm{Al}_{2} \mathrm{O}_{3}$-supported catalyst prepared from $\left[\mathrm{Os}(\mathrm{CO})_{5}\right]$ (9).

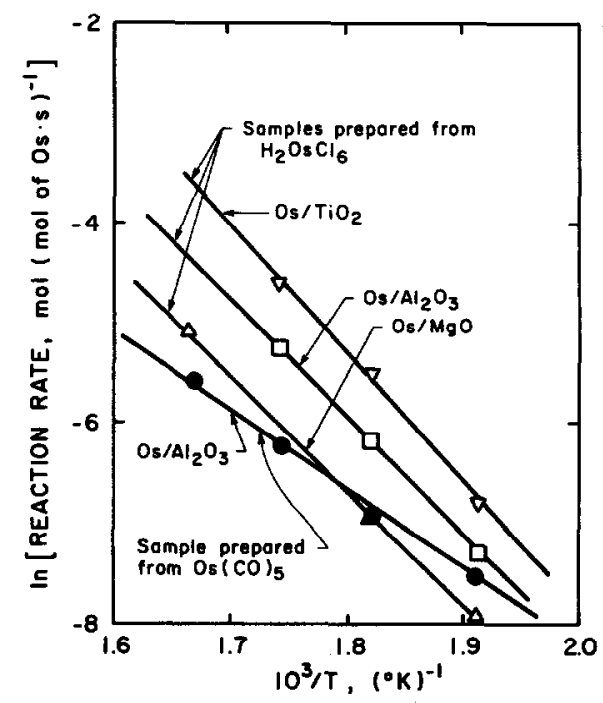

Fig. 2. Temperature dependence of $\mathrm{CO}$ hydrogenation rate at $10 \mathrm{~atm}$ with a $\mathrm{H}_{2} / \mathrm{CO}$ molar ratio of $1 / 1$. 

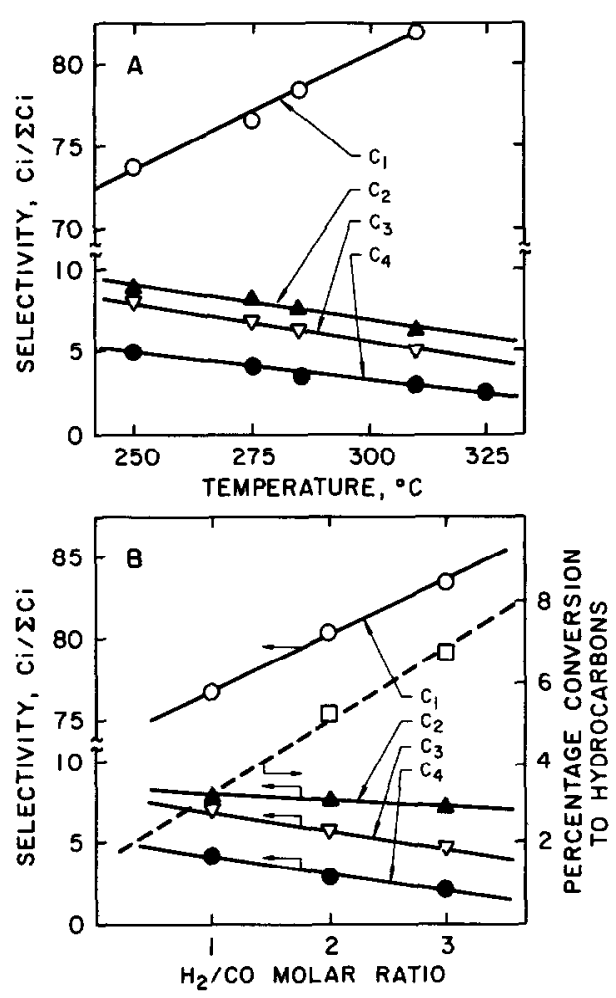

FIG. 3. (A) Temperature dependence of selectivity in $\mathrm{CO}$ hydrogenation catalyzed by $5 \% \mathrm{Os} / \mathrm{Al}_{2} \mathrm{O}_{3}$ prepared from $\left[\mathrm{H}_{2} \mathrm{OsCl}_{6}\right]$. (B) Dependence of selectivity on $\mathrm{H}_{2} / \mathrm{CO}$ molar ratio at $275^{\circ} \mathrm{C}$ and $10 \mathrm{~atm}$ with $5 \mathrm{wt} \%$ $\mathrm{Os} / \mathrm{Al}_{2} \mathrm{O}_{3}$ prepared from $\left[\mathrm{H}_{2} \mathrm{OsCl}_{6}\right]$.

The effects of temperature and feed-gas composition on product distribution for the $\mathrm{Al}_{2} \mathrm{O}_{3}$-supported catalyst are shown in Fig. 3. Methane was the predominant hydrocarbon formed on all the catalysts, accounting for $74-84 \%$ of the total products with Os/ $\mathrm{Al}_{2} \mathrm{O}_{3}$ (Table 3). The selectivity to methane increased, but the selectivity to $\mathrm{C}_{2}-\mathrm{C}_{4}$ hydrocarbons decreased as the reaction temperature increased from 250 to $325^{\circ} \mathrm{C}$ (Fig. $3 A)$. Both the percentage conversion to hydrocarbons and the selectivity to methane increased as the $\mathrm{H}_{2} / \mathrm{CO}$ feed ratio increased, whereas the selectivity to $C_{2}-C_{4}$ hydrocarbons decreased (Fig. 3B).

The olefin/paraffin ratio observed with the $\mathrm{Al}_{2} \mathrm{O}_{3}$-supported catalyst decreased with increasing $\mathrm{H}_{2} / \mathrm{CO}$ ratio and (except for $\mathrm{C}_{2}$ ) with increasing temperature $>275^{\circ} \mathrm{C}$ (Table 3). The olefin/paraffin ratio was

higher for the $\mathrm{Al}_{2} \mathrm{O}_{3}$-supported catalyst than for the $\mathrm{MgO}$ - and $\mathrm{TiO}_{2}$-supported catalysts (Tables 2 and 3).

The hydrocarbon products conformed to a Schulz-Flory distribution of chiefly straight-chain hydrocarbons; typical data are shown in Fig. 4. Hydrocarbons heavier than $\mathrm{C}_{7}$ were not observed at the low conversions investigated in these experiments.

\section{Performance of Catalysts Prepared from \\ $\left[\mathrm{Os}_{3}(\mathrm{CO})_{12}\right],\left[\mathrm{H}_{4} \mathrm{Os}_{4}(\mathrm{CO})_{12}\right]$, and $\left[\mathrm{Os}_{6}(\mathrm{CO})_{18}\right]$}

All the $\mathrm{Al}_{2} \mathrm{O}_{3}$-supported catalysts prepared from metal clusters were active for $\mathrm{CO}$ hydrogenation, giving both hydrocarbons and oxygenated products. Dimethyl ether was the only observed oxygenated product. Since methanol is rapidly dehydrated to give dimethyl ether on the $\gamma-\mathrm{Al}_{2} \mathrm{O}_{3}$ support (10), we infer that the ether was a secondary product formed from methanol. The activity of the cluster-derived catalysts for oxygenate formation was about 2 orders

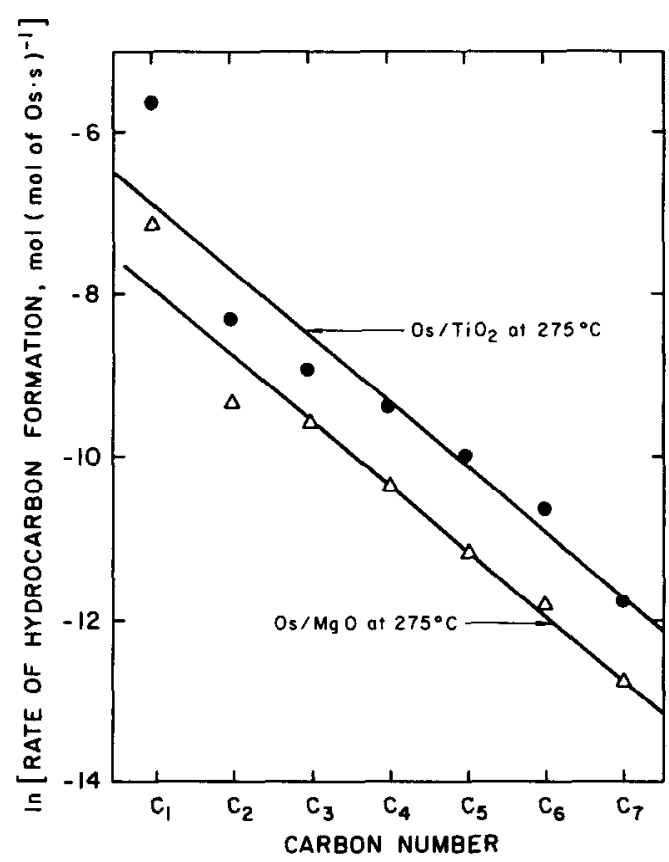

FIG. 4. Schulz-Flory plot for reaction at 10 atm with a $\mathrm{H}_{2} / \mathrm{CO}$ molar ratio of $1 / 1$; the catalysts were prepared from $\left[\mathrm{H}_{2} \mathrm{OsCl}_{6}\right]$. 
TABLE 4

$\gamma$ - $\mathrm{Al}_{2} \mathrm{O}_{3}$-Supported $\mathrm{CO}$ Hydrogenation Catalysts

\begin{tabular}{|c|c|c|c|c|c|}
\hline $\begin{array}{l}\text { Catalyst } \\
\text { precursor }\end{array}$ & $\begin{array}{c}\text { Os } \\
(w t \%)\end{array}$ & $\begin{array}{c}\text { Approx average particle size } \\
\text { determined by TEM } \\
(\AA)\end{array}$ & $\begin{array}{c}10^{4} r_{\mathrm{HC}}(\mathrm{mol} \\
\left.(\mathrm{mol} \text { of total Os } \cdot \mathrm{s})^{-1}\right)^{a}\end{array}$ & $r_{\mathrm{HC}}^{b / r_{\text {ether }}}$ & Ref. \\
\hline$\left[\mathrm{Os}(\mathrm{CO})_{5}\right]$ & 0.36 & $\leq 25^{c}$ & 10.4 & $-d$ & (9) \\
\hline$\left[\mathrm{Os}(\mathrm{CO})_{3}\right]$ & 0.36 & $\leq 17^{e}$ & 2.5 & - & (9) \\
\hline$\left[\mathrm{Os}_{3}(\mathrm{CO})_{12}\right]$ & 1.8 & 10 to $20+$ large particles & 1.9 & 25 & This work \\
\hline$\left[\mathrm{H}_{4} \mathrm{Os}_{4}(\mathrm{CO})_{12}\right]$ & 1.8 & 10 & 4.1 & 50 & This work \\
\hline$\left[\mathrm{Os}_{6}(\mathrm{CO})_{18}\right]$ & 1.8 & 10 to 20 & 10 & 160 & This work \\
\hline$\left[\mathrm{H}_{2} \mathrm{OsCl}_{6}\right]$ & 5 & 70 & 18 & 490 & This work \\
\hline
\end{tabular}

a Rate of total hydrocarbon formation at $275^{\circ} \mathrm{C}$ and $10 \mathrm{~atm}$ with a $\mathrm{H}_{2} / \mathrm{CO}$ molar ratio of 1 .

${ }^{b}$ Rate of total hydrocarbon formation divided by rate of dimethyl ether formation at $275^{\circ} \mathrm{C}$ and $10 \mathrm{~atm}$.

c Reduction for $>10 \mathrm{~h}$ (Table 1); appreciable aggregation of Os was reported (9).

${ }^{d}$ Small amounts of ether were observed but not determined quantitatively ( 9 ).

- Reduction for $1 \mathrm{~h}$ (Table 1); only a few aggregates were observed (9).

of magnitude lower than the activity for hydrocarbon formation (Table 4).

The activities of the cluster-derived catalysts, like those of the catalysts prepared from $\left[\mathrm{H}_{2} \mathrm{OsCl}_{6}\right.$ ] (Fig. 1), were relatively high initially, decreasing with time on stream and becoming nearly constant after $25 \mathrm{~h}$ on stream (Fig. 5). In contrast, the activity for dimethyl ether formation in-

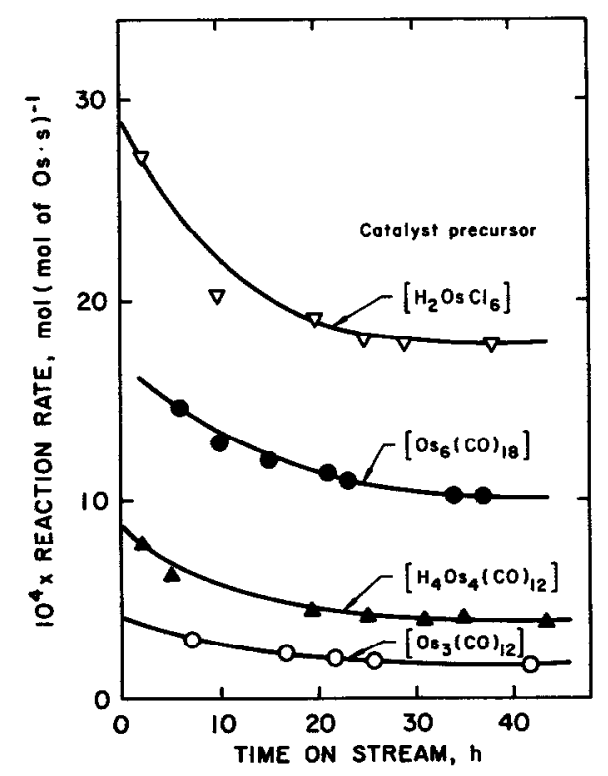

FiG. 5. Break-in rates of hydrocarbon formation catalyzed by $\gamma-\mathrm{Al}_{2} \mathrm{O}_{3}$-supported $\mathrm{Os}$ catalysts. Reaction conditions: $275^{\circ} \mathrm{C}, 10 \mathrm{~atm}, \mathrm{H}_{2} / \mathrm{CO}$ molar ratio of $1 / 1$. creased with time on stream, also becoming nearly constant after $25 \mathrm{~h}$ on stream (Fig. 6). The data of Fig. 7 for the catalyst prepared from $\left[\mathrm{H}_{4} \mathrm{Os}_{4}(\mathrm{CO})_{12}\right]$ and $\mathrm{Al}_{2} \mathrm{O}_{3}$ clearly illustrate the pattern of catalyst break-in, demonstrating that steady-state activity for both hydrocarbon and ether formation was

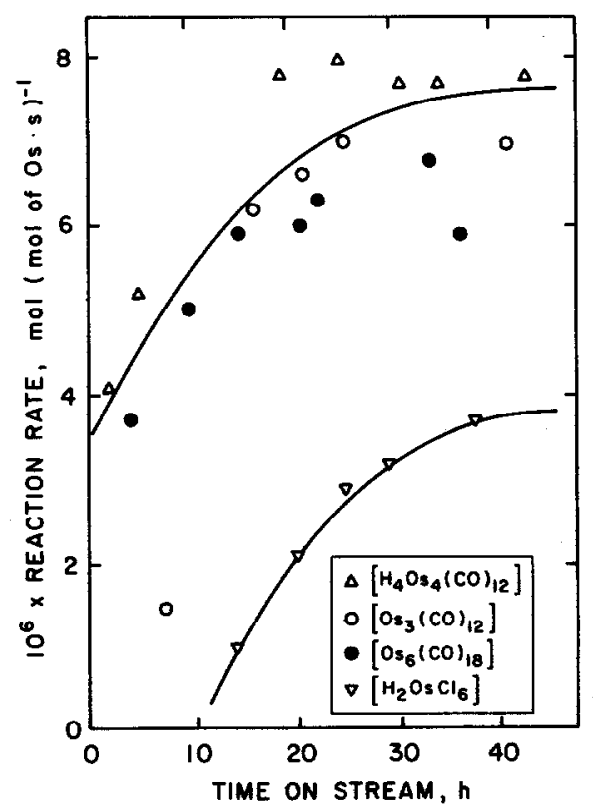

Fig. 6. Break-in rates of oxygenate formation for $\gamma$ $\mathrm{Al}_{2} \mathrm{O}_{3}$-supported $\mathrm{Os}$ prepared from different precursors (identified by symbols). Reaction conditions as shown for Fig. 5. 
attained after the same period. An activation energy of $22.1 \mathrm{kcal} / \mathrm{mol}$ was measured for the hydrocarbon formation in the presence of the catalyst prepared from $\left[\mathrm{H}_{4} \mathrm{Os}_{4}(\mathrm{CO})_{12}\right]$ and $\gamma-\mathrm{Al}_{2} \mathrm{O}_{3}$.

The results obtained with the catalysts prepared from Os clusters (summarized in Table 4) show that the activity for hydrocarbon formation incrcased with increasing nuclearity of the precursor cluster. The activity for oxygenate formation was almost independent of precursor nuclearity. Methane was the predominant hydrocarbon; the selectivity to methane increased and the selectivity to $\mathrm{C}_{2}$ hydrocarbons decreased with increasing nuclearity of the precursor cluster. The selectivity to the other hydrocarbons appeared to be unaffected by cluster nuclearity; there was no apparent effect of the cluster nuclearity on the olefin/paraffin ratio. This ratio was, however, higher for the cluster-derived catalysts than for those derived from $\left[\mathrm{H}_{2} \mathrm{OsCl}_{6}\right]$ and $\left[\mathrm{Os}(\mathrm{CO})_{5}\right]$.

\section{Performance of Catalysts Prepared from $\left[\mathrm{Os}(\mathrm{CO})_{5}\right](9)$}

The alumina-supported catalyst prepared from $\left[\mathrm{Os}(\mathrm{CO})_{5}\right]$ and reduced in flowing hydrogen for $1 \mathrm{~h}$ at $275^{\circ} \mathrm{C}$ was also active for the synthesis of hydrocarbons from $\mathrm{CO}+$ $\mathrm{H}_{2}$ (9). It was more active than the catalyst prepared from $\left[\mathrm{Os}_{3}(\mathrm{CO})_{12}\right]$ but less active than those prepared from the tetranuclear and hexanuclear osmium carbonyls. The rate of oxygenate formation catalyzed by the sample derived from $\left[\mathrm{Os}(\mathrm{CO})_{5}\right]$ was at least an order of magnitude lower than the rates observed with the cluster-derived catalysts. When the $\left[\mathrm{Os}(\mathrm{CO})_{5}\right]$-derived catalyst was reduced in flowing $\mathrm{H}_{2}$ for $>10 \mathrm{~h}$ at $275^{\circ} \mathrm{C}$, a higher activity for formation of hydrocarbons was observed (Table 4). The activity was then as great as that of the $\left[\mathrm{Os}_{6}(\mathrm{CO})_{18}\right]$-derived catalyst. The selectivity to methane also increased with increasing severity of reduction, becoming comparable in magnitude to the values observed with the cluster-derived catalysts. Even in this highly active form, however, the cata-

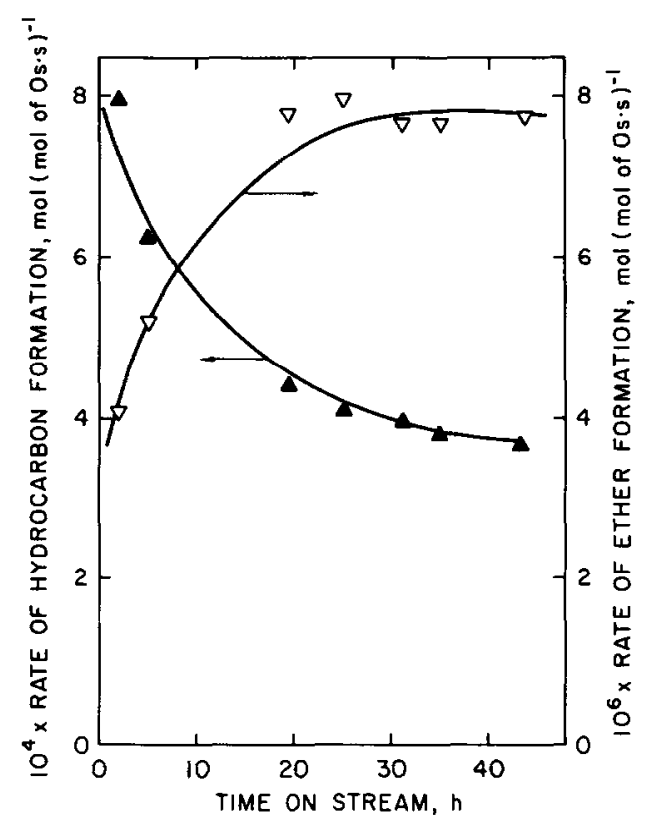

FiG. 7. Break-in rates of hydrocarbon and dimethyl ether formation in the presence of catalyst prepared from $\left[\mathrm{H}_{4} \mathrm{Os}_{4}(\mathrm{CO})_{12}\right]$ and $\gamma-\mathrm{Al}_{2} \mathrm{O}_{3}$. Reaction conditions as shown for Fig. 5 .

lyst derived from $\left[\mathrm{Os}(\mathrm{CO})_{5}\right]$ was still not as active as the $\mathrm{Al}_{2} \mathrm{O}_{3}$-supported catalyst prepared from $\left[\mathrm{H}_{2} \mathrm{OsCl}_{6}\right]$.

\section{Characterization of Catalysts by Electron Microscopy}

In earlier work it was found that the fresh $\mathrm{Al}_{2} \mathrm{O}_{3}$-supported triosmium cluster samples gave rise to only faint scattering centers that became more pronounced after treatment in $\mathrm{He}$ at $200^{\circ} \mathrm{C}$, which led to cluster breakup (6). Therefore, the cluster-derived samples were initially treated in flowing $\mathrm{He}$ at $200^{\circ} \mathrm{C}$ prior to characterization by $\mathrm{mi}-$ croscopy; they were stored in air at room temperature following the treatment in $\mathrm{He}$.

The $\gamma-\mathrm{Al}_{2} \mathrm{O}_{3}$ support in some regions showed an amorphous grainy structure and in others a characteristic regular structure inferred to arise from lattice fringes. In no case did the $\gamma-\mathrm{Al}_{2} \mathrm{O}_{3}$ support itself show any scattering centers comparable to those attributed to Os (6). The samples of catalyst prepared from $\left[\mathrm{Os}_{3}(\mathrm{CO})_{12}\right]$, after treatment 

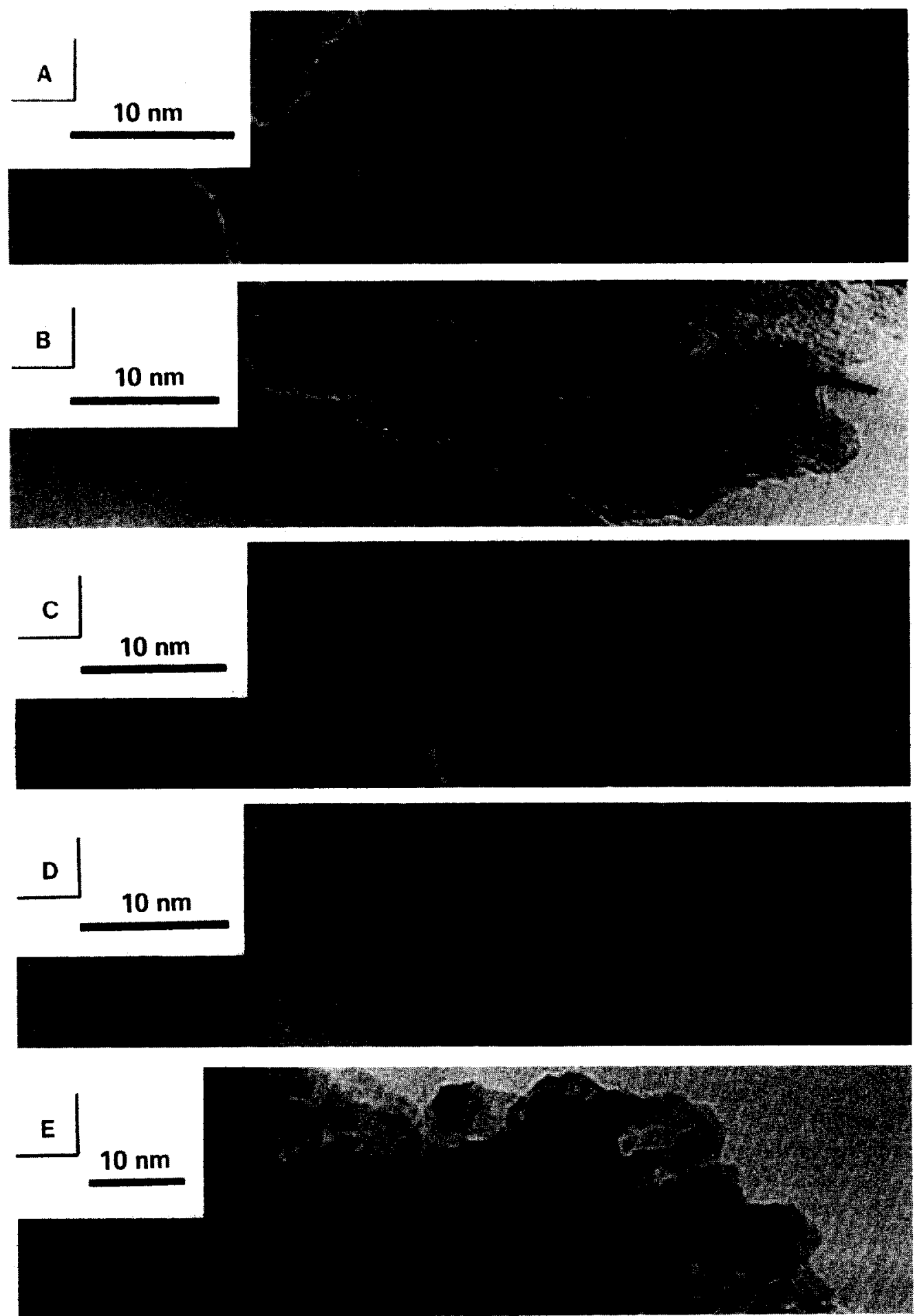

FIG. 8. (A) Micrograph of the catalyst derived from $\left[\mathrm{Os}_{3}(\mathrm{CO})_{12}\right]$ after treatment in flowing $\mathrm{He}$ at $200^{\circ} \mathrm{C}$. (B) Micrograph of the catalyst derived from $\left[\mathrm{Os}_{6}(\mathrm{CO})_{18}\right]$ after treatment in flowing $\mathrm{He}$ at $200^{\circ} \mathrm{C}$. (C) Micrograph of the catalyst derived from $\left[\mathrm{Os}_{3}(\mathrm{CO})_{12}\right]$ after being used for $\mathrm{CO}$ hydrogenation. (D) Micrograph of the catalyst derived from $\left[\mathrm{H}_{4} \mathrm{Os}_{4}(\mathrm{CO})_{12}\right]$ after being used for $\mathrm{CO}$ hydrogenation. (E) Micrograph of the catalyst derived from $\left[\mathrm{Os}_{6}(\mathrm{CO})_{18}\right]$ after being used for $\mathrm{CO}$ hydrogenation. 
in $\mathrm{He}$, had clearly visible scattering centers smaller than $10 \AA$ (Fig. 8A), consistent with the presence of three-atom ensembles; the observations are entirely consistent with those reported previously (6). The catalyst prepared from $\left[\mathrm{H}_{4} \mathrm{Os}_{4}(\mathrm{CO})_{12}\right]$, subjected to the identical treatment in $\mathrm{He}$ at $200^{\circ} \mathrm{C}$, gave only faint scattering centers. The observed contrast was too weak to allow an unambiguous conclusion with regard to the presence of ensembles of four Os atoms. The sample prepared from $\left[\mathrm{Os}_{6}(\mathrm{CO})_{18}\right]$ appeared to be very similar to that prepared from triosmium clusters (Fig. 8B). Numerous scattering centers smaller than $10 \AA$ were clearly visible. Although the sizes of the particles in Fig. 8B appear to be slightly greater than those of Fig. 8A, it is not possible to attach statistical significance to the difference. To relate the apparent sizes of these particles to the true sizes would require detailed image calculations (11). The data of Fig. 8B are judged to be consistent with the presence of six-atom ensembles.

The samples used for $\mathrm{CO}$ hydrogenation for $40 \mathrm{~h}$ at $275^{\circ} \mathrm{C}$ and $10 \mathrm{~atm}$ with an equimolar $\mathrm{CO}+\mathrm{H}_{2}$ mixture flowing at $20 \mathrm{~cm}^{3} /$ min all contained larger aggregates (or crystallites) of Os. The samples prepared from $\left[\mathrm{Os}_{3}(\mathrm{CO})_{12}\right]$ had a significant fraction of aggregates smaller than $10 \AA$, many in the range of 10-20 $\AA$, and a few even larger (Fig. 8C). The used catalyst prepared from $\left[\mathrm{H}_{4} \mathrm{Os}_{4}(\mathrm{CO})_{12}\right]$ had scattering centers about $10 \AA$ in diameter (Fig. 8D); no significantly larger particles were visible. The sample prepared from $\left[\mathrm{Os}_{6}(\mathrm{CO})_{18}\right]$ consisted of a distribution of larger crystallites, most of them about $20 \AA$ in diameter, along with aggregates of the original size ( $<10 \AA$ ) (Fig. $8 \mathrm{E}$ ). Examination of the thicker regions of all these samples confirmed that no crystallites larger than about $20 \AA$ were present in the observed regions.

The samples of used catalyst prepared from $\left[\mathrm{H}_{2} \mathrm{OsCl}_{6}\right]$ were found to have relatively large crystallites; a typical dimension was $70 \AA$.

\section{Catalyst Characterization by $\mathrm{H}_{2}$ and $\mathrm{CO}$ Chemisorption}

The relatively low dispersion of Os in the catalysts prepared from $\left[\mathrm{H}_{2} \mathrm{OsCl}_{6}\right]$ is confirmed by the results of room-temperature chemisorption measurements with fresh samples, summarized in Table 1 . The H/Os ratio obtained from extrapolating the adsorption data to zero pressure was between 0.11 and 0.30 , with the higher value observed with the $\mathrm{Al}_{2} \mathrm{O}_{3}$-supported sample. The similarly measured ratios of $\mathrm{CO} / \mathrm{Os}$ were about the same, except for the unexplained case of the $\mathrm{TiO}_{2}$-supported catalyst, which adsorbed twice as much $\mathrm{CO}$.

\section{Infrared Spectra of Catalysts}

$\left[\mathrm{Os}_{3}(\mathrm{CO})_{12}\right] / \mathrm{Al}_{2} \mathrm{O}_{3}$. The infrared spectra of the $\mathrm{Al}_{2} \mathrm{O}_{3}$-supported catalyst prepared from the triosmium cluster are consistent with the reported spectra $(1,2,10,12)$. The fresh sample at $22^{\circ} \mathrm{C}$ exhibited bands in the carbonyl region similar to those reported. Slight changes indicative of decarbonylation were evident after heating of the sample in flowing $\mathrm{He}$ at $150^{\circ} \mathrm{C}$ for $1 \mathrm{~h}$. After further heating in $\mathrm{He}$ to $275^{\circ} \mathrm{C}$ and a 1-h reduction with flowing $\mathrm{H}_{2}$ at $275^{\circ} \mathrm{C}$, a threeband spectrum resembling that of the mononuclear complex formed by cluster break-up $(1,2,10,12)$ was observed: $2127 \mathrm{w}, 2021 \mathrm{~s}$, and $1932-1930 \mathrm{sm}^{-1}$. Upon exposure of this sample to an equimolar $\mathrm{CO}$ $+\mathrm{H}_{2}$ mixture for $1 \mathrm{~h}$ followed by evacuation at $275^{\circ} \mathrm{C}$, the band positions had become 2122, 2022, and $1933 \mathrm{~cm}^{-1}$, but the relative intensity of the band at $1933 \mathrm{~cm}^{-1}$ had decreased. When this sample was again treated with $\mathrm{H}_{2}$ at $275^{\circ} \mathrm{C}$ for $1 \mathrm{~h}$, bands were formed at 2127, 2025-2028, and $1934 \mathrm{~cm}^{-1}$, with an increase in the relative intensity of the band at $1934 \mathrm{~cm}^{-1}$. The bands at 20252028 and at $1934 \mathrm{~cm}^{-1}$ have been assigned to carbonyls of Os in oxidation states lower than +2 (2).

A sample of the catalyst which had been treated with $\mathrm{He}$ and $\mathrm{H}_{2}$ as indicated above 

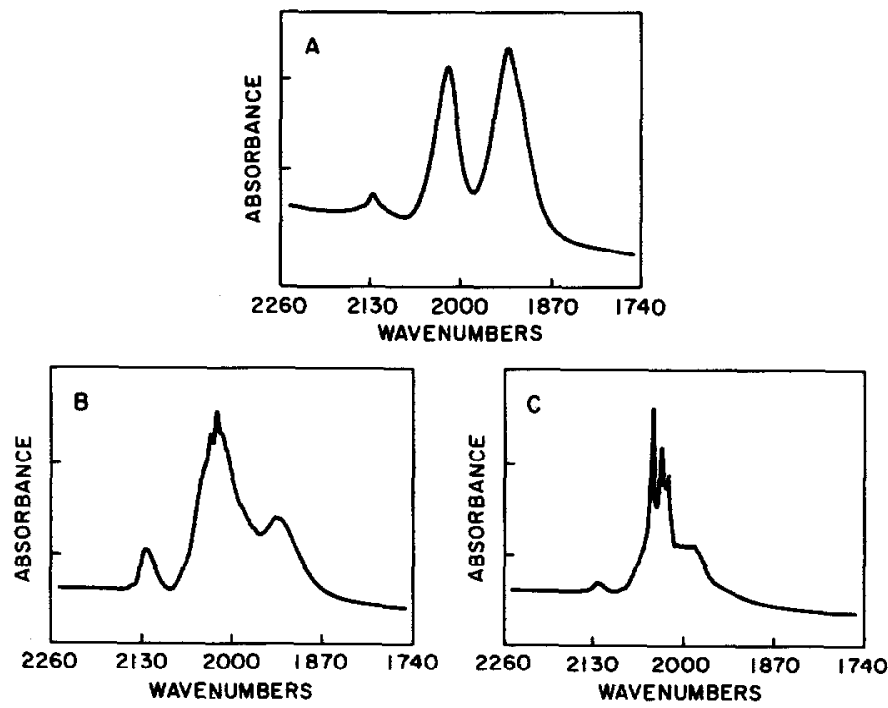

Fig. 9. Infrared spectra of the sample prepared from $\left[\mathrm{H}_{4} \mathrm{Os}_{4}(\mathrm{CO})_{12}\right]$ and $\gamma-\mathrm{Al}_{2} \mathrm{O}_{3}$. (A) Fresh sample after $2 \mathrm{~h}$ in $\mathrm{He}$ at $275^{\circ} \mathrm{C}$. (B) Fresh sample after $1 \mathrm{~h}$ in $\mathrm{CO}+\mathrm{H}_{2}$ after a He flush at $275^{\circ} \mathrm{C}$. (C) Used catalyst sample, evacuated at $26^{\circ} \mathrm{C}$.

and then used for $\mathrm{CO}$ hydrogenation also had bands suggestive of the broken-up cluster $\left(2125,2033\right.$, and $\left.1949 \mathrm{~cm}^{-1}\right)$. When this used sample was heated in $\mathrm{H}_{2}$ at $275^{\circ} \mathrm{C}$ for 1 h, a more complex spectrum was formed, with bands at $2144 \mathrm{vw}, 2127 \mathrm{w}, 2066 \mathrm{wsh}$, $2050 \mathrm{wsh}, 2025 \mathrm{~s}$, and $1935 \mathrm{~m} \mathrm{~cm}^{-1}$. Upon treatment of the sample with the $\mathrm{CO}+\mathrm{H}_{2}$ mixture for $1 \mathrm{~h}$ at $275^{\circ} \mathrm{C}$, a simple threeband spectrum again appeared $(2125,2022$, and $1940 \mathrm{~cm}^{-1}$ ). Another hour's treatment with $\mathrm{H}_{2}$ at $275^{\circ} \mathrm{C}$ led to the more complex spectrum mentioned above. The three-band spectrum $\left(2127 \mathrm{w}, 2025 \mathrm{~s}\right.$, and $\left.1935 \mathrm{~m} \mathrm{~cm}^{-1}\right)$ was evident, but there were also weak bands at 2144, 2067, and $2050 \mathrm{~cm}^{-1}$.

$\left[\mathrm{H}_{4} \mathrm{Os}_{4}(\mathrm{CO})_{12}\right] / \mathrm{Al}_{2} \mathrm{O}_{3}$. A fresh sample prepared from the $\mathrm{Al}_{2} \mathrm{O}_{3}$-supported tetranuclear cluster had a relatively complex spectrum (2113vw, 2088s, 2057vs, 2062vs, $2010 \mathrm{vs} \mathrm{cm}^{-1}$ ). Heating the sample in flowing $\mathrm{He}$ at $150^{\circ} \mathrm{C}$ for $1 \mathrm{~h}$ did not result in any significant change in the spectrum. Changes began to occur during $\mathrm{H}_{2}$ treatment, and after about $2 \mathrm{~h}$ in $\mathrm{H}_{2}$ at $275^{\circ} \mathrm{C}$, the sample exhibited a three-band pattern suggestive of the mononuclear osmium carbonyl com- plex (Fig. 9A). The band positions were 2128,2022 , and $1937 \mathrm{~cm}^{-1}$. When this sample was treated with an equimolar $\mathrm{CO}+\mathrm{H}_{2}$ mixture for $1 \mathrm{~h}$ at $275^{\circ} \mathrm{C}$, the relative intensity of the (slightly shifted) band at 2125 $\mathrm{cm}^{-1}$ increased while that of the (slightly shifted) band at $1938 \mathrm{~cm}^{-1}$ decreased. A new band was also formed at $2034 \mathrm{~cm}^{-1}$ (Fig. 9B). Exposure of this sample to an equilmolar $\mathrm{CO}+\mathrm{H}_{2}$ mixture at $275^{\circ} \mathrm{C}$ for $7.5 \mathrm{~h}$ did not produce any further changes. However, when this sample was again exposed to flowing $\mathrm{H}_{2}$ for $1 \mathrm{~h}$ at $275^{\circ} \mathrm{C}$, a simple three-band pattern emerged, with the relative intensity of the (slightly shifted) band at $1936 \mathrm{~cm}^{-1}$ increased.

Spectrum C of Fig. 9 was obtained with the sample which had been used for catalytic hydrogenation of $\mathrm{CO}$. The spectrum is different from that of the fresh sample and from those of the pretreated samples (Figs. 9A and B), and it is clear that significant structural changes had taken place.

$\left[\mathrm{Os}_{6}(\mathrm{CO})_{18}\right] / \mathrm{Al}_{2} \mathrm{O}_{3}$. The spectrum of the fresh sample prepared from $\mathrm{Al}_{2} \mathrm{O}_{3}$ and the hexaosmium cluster measured in $\mathrm{He}$ at $23^{\circ} \mathrm{C}$ included bands at $2117,2086,2034$, 

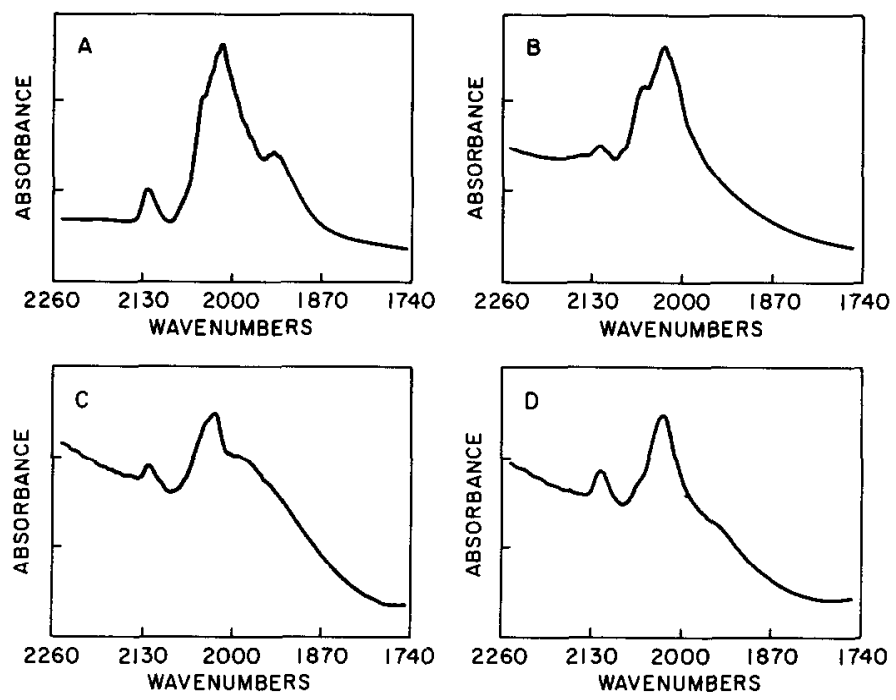

FIG. 10. Infrared spectra sample prepared from $\left[\mathrm{Os}_{6}(\mathrm{CO})_{18}\right]$ and $\gamma-\mathrm{Al}_{2} \mathrm{O}_{3}$. (A) Fresh sample after $1 \mathrm{~h}$ in $\mathrm{CO}+\mathrm{H}_{2}$ and evacuation at $275^{\circ} \mathrm{C}$. (B) Used sample evacuated at $23^{\circ} \mathrm{C}$. (C) Used sample after $1 \mathrm{~h}$ in $\mathrm{He}$ at $150^{\circ} \mathrm{C}$. (D) Used sample after $1 \mathrm{~h}$ in $\mathrm{CO}+\mathrm{H}_{2}$ and evacuation at $150^{\circ} \mathrm{C}$.

2025 , and $1940 \mathrm{~cm}^{-1}$. Upon heating of this sample in $\mathrm{He}$ at $150^{\circ} \mathrm{C}$ for $1 \mathrm{~h}$, a slight change occurred in the spectrum; the band at $1940 \mathrm{~cm}^{-1}$ became weak and broad. After 1-h exposure to flowing $\mathrm{H}_{2}$ at $275^{\circ} \mathrm{C}$, a three-band spectrum suggestive of the mononuclear osmium complex was observed (2127w, 2020-2030s, and 1930$1940 \mathrm{~s} \mathrm{~cm}^{-1}$ ). The relative intensity of the band at 1930-1940 $\mathrm{cm}^{-1}$ was increased by treatment with $\mathrm{H}_{2}$ at $275^{\circ} \mathrm{C}$. When this sample was exposed to flowing $\mathrm{CO}+\mathrm{H}_{2}$ (equimolar) at $275^{\circ} \mathrm{C}$ and then evacuated at $275^{\circ} \mathrm{C}$, a spectrum emerged with some shoulders accompanying the band at 2020 $2030 \mathrm{~cm}^{-1}$ (Fig. 10A). The relative intensity of the band at $1939 \mathrm{~cm}^{-1}$ had again decreased when the sample was exposed to the $\mathrm{CO}+\mathrm{H}_{2}$ mixture.

The spectrum of the sample of catalyst which had been used for $\mathrm{CO}$ hydrogenation, after evacuation at $23^{\circ} \mathrm{C}$, is shown in Fig. 10B. A comparison with the spectrum of the fresh sample shows that decarbonylation had taken place and that the band at $1940 \mathrm{~cm}^{-1}$ had disappeared. Further decarbonylation occurred following 1 -h heating in flowing $\mathrm{He}$ at $150^{\circ} \mathrm{C}$ (Fig. 10C); however, a broad shoulder had formed at $1940 \mathrm{~cm}^{-1}$. This shoulder disappeared upon treatment of the sample with equilmolar $\mathrm{CO}+\mathrm{H}_{2}$ for $1 \mathrm{~h}$ at $150^{\circ} \mathrm{C}$ (Fig. 10D).

\section{CO Hydrogenation in a Batch Reactor}

In a few preliminary experiments, methane formation in a batch reactor was followed by mass spectrometry, and the results were correlated with the infrared spectra of the same catalysts obtained after treatment under identical conditions. The reaction conditions in these experiments were $300^{\circ} \mathrm{C}$ and $0.53 \mathrm{~atm}$ with a $\mathrm{CO} / \mathrm{H}_{2}$ molar ratio of $1 / 1$. When the catalyst prepared from $\left[\mathrm{Os}_{3}(\mathrm{CO})_{12}\right.$ ] was pretreated in $\mathrm{CO}$ at $400^{\circ} \mathrm{C}$, the bands at 2128 and $2040 \mathrm{~cm}^{-1}$ characteristic of the mononuclear dicarbonyl of divalent Os $(1,2,10,12)$ were observed. Evacuation at the same temperature led to the well-known three-band spectrum $\left(2128,2050\right.$, and $\left.1976 \mathrm{~cm}^{-1}\right)$, which has been attributed to the presence of both di- and tricarbonyl species of divalent Os $(1,2,10,12)$. Methane formation was not observed after these treatments. 
However, $\mathrm{H}_{2}$ pretreatment at $1 \mathrm{~atm}$ and $375^{\circ} \mathrm{C}$ produced bands at 2020 and 1930 $\mathrm{cm}^{-1}$, and methane formation was observed. Similarly, all catalysts which did produce methane gave rise to these lowfrequency bands after use. These results suggest that the corresponding surface complexes-presumably dicarbonyls of Os in oxidation states lower than $+2(2)$-may have played a role in the catalytic conversion of $\mathrm{CO}$ and $\mathrm{H}_{2}$ to form methane.

\section{DISCUSSION}

The results show that osmium clusters provide the opportunity for preparation of highly dispersed supported metal catalysts; 10 - to $20-\AA \AA$ aggregates are the predominant metal species in the catalysts. These aggregates are evidently stable during $\mathrm{CO}$ hydrogenation; we suggest that the $\mathrm{CO}$ helps to stabilize them, much as it stabilizes metal clusters such as $\left[\mathrm{Os}_{3}(\mathrm{CO})_{12}\right]$ in solution (13).

The infrared spectra indicate that the initial Os species on the $\mathrm{Al}_{2} \mathrm{O}_{3}$ were clusters of the same nuclearity as the molecular precursors. For triosmium, the conclusion is firmly established by the spectra, the electron micrographs, and the literature (1-7). The conclusion is also firmly established for the tetraosmium. Separate experiments done with $\left[\mathrm{H}_{4} \mathrm{Os}_{4}(\mathrm{CO})_{12}\right]$ brought in contact with $\gamma-\mathrm{Al}_{2} \mathrm{O}_{3}$ in refluxing $n$-octane indicated that the relatively stable anion cluster $\left[\mathrm{H}_{3} \mathrm{Os}_{4}(\mathrm{CO})_{12}\right]^{-}$was formed (14), consistent with the spectrum observed in this work; the anion cluster could be extracted from the surface as the tetraphenylarsonium salt (14). The structures of the species derived from the hexaosmium cluster remain to be determined.

The spectra of the cluster-derived catalysts indicate that the clusters were broken up during catalyst pretreatment; the spectra of the used catalysts show that new structures had formed. We suggest that the sizes of these new structures are related to the number of Os atoms in the ensembles from which they formed, presumably by reduction, surface migration, and aggregation.

The electron microscopy indicates that the smallest Os particles existed in the catalyst derived from the tetranuclear clusters. Since the infrared spectra indicate the formation of the relatively stable tetranuclear cluster anions on the surface of this catalyst, we speculate that this structure might have been reconstituted in the presence of $\mathrm{CO}+$ $\mathrm{H}_{2}$ and that its relatively high stability might have hindered the reduction and aggregation that took place on the other catalysts.

Catalysts prepared conventionally by aqueous impregnation of the $\mathrm{Al}_{2} \mathrm{O}_{3}$ support with $\left[\mathrm{H}_{2} \mathrm{OsCl}_{6}\right]$ also typically have high dispersions. A high loading of Os (5wt\%) was used to produce larger crystallites of Os, having a dispersion of $0.1-0.3$, measured by $\mathrm{H}_{2}$ chemisorption. This sample allowed a comparison of catalysts having a wide range of dispersions. The Os surface areas estimated from the hydrogen chemisorption data were used to estimate the reaction rates per exposed Os atom; the results are shown in Table 2.

The catalytic activity data summarized in Table 4 demonstrate a trend of increasing activity with increasing Os particle size. The results suggest a parallel with those observed for supported $\mathrm{Ru}$ and $\mathrm{Fe}$ catalysts (15). The particle size effect is large; we emphasize that the rates summarized in Table 4 are reported per total Os atom of the catalyst; these rates are therefore less than the turnover frequencies, but for the highly dispersed cluster-derived catalysts, they are good approximations of the turnover frequencies. The turnover frequency is presented in Table 4 for the catalyst with low dispersion prepared from $\left[\mathrm{H}_{2} \mathrm{OsCl}_{6}\right]$ (the hydrogen chemisorption measurements were made with this sample). This catalyst has a normalized activity an order of magnitude greater than those of the cluster-derived catalysts.

The approximate turnover frequencies in Table 4 are believed to be the first reported for CO hydrogenation catalyzed by Os. 
Comparison of the activity of Os with those of other metals is difficult, however, since turnover frequencies have not been reported for other metals under the same conditions and since the literature (16) indicates wide variations in rate laws, which implies that extrapolations are risky.

The appearance of dimethyl ether in the $\mathrm{CO}$ hydrogenation products is a new result for the osmium catalysts. We note that the infrared spectra of the carbonylated used catalysts suggest the three-band pattern indicative of $\mathrm{Os}(\mathrm{II})(\mathrm{CO})_{x}$, where $x=2$ or 3 . This pattern has been observed before with catalysts containing $4 \mathrm{wt} \%$ Os prepared from $\left[\mathrm{H}_{2} \mathrm{OsCl}_{6}\right](10)$. It has been suggested (10) that in highly dispersed Os catalysts, $\mathrm{CO}$ may oxidize a fraction of the Os atoms to give the divalent carbonyl complexes [similar oxidation of dispersed $\mathrm{Rh}$ to $\mathrm{Rh}(\mathrm{I})$ has been reported (17)]. We speculate that these are the catalytically active species for methanol formation and that the break-in period (Fig. 6) is associated with their formation. We further speculate that the decrease in activity for hydrocarbon formation in the break-in period (Figs. 5 and 7) may be associated with the removal by oxidation of zero-valent Os, although the effects of carbonaceous residues and sintering of Os cannot be ruled out, particularly for the catalyst prepared from $\mathrm{H}_{2} \mathrm{OsCl}_{6}$. It has been suggested that cationic Pd (18) and $\mathrm{Rh}(19)$ are involved in methanol formation. Mononuclear complexes of Os (presumably in oxidation states lower than +2 ) might also be involved in methane formation.

\section{ACKNOWLEDGMENTS}

We thank Y. Zhao for performing the batch reactor experiment. Adsorption data were furnished by E. E. Carroll, Jr., of the Du Pont Central Research and Development Department. This work was supported by the National Science Foundation and the Deutsche Forschungsgemeinschaft.

\section{REFERENCES}

1. Psaro, R., Ugo, R. Zanderighi, G. M., Besson, B., Smith, A. K., and Basset, J. M., J. Organomet. Chem. 213, 215 (1981).

2. Knözinger, H., Zhao, Y., Barth, R., Epstein, R., Gates, B. C., and Scott, J. P., Faraday Discuss. Chem. Soc. 72, 53 (1981).

3. Besson, B., Moraweck, B., Smith, A. K., Basset, J. M., Psaro, R., Fusi, A., and Ugo, R., J. Chem. Soc. Chem. Commun., 569 (1980).

4. Li, X.-J., and Gates, B. C., J. Catal. 84, 55 (1983).

5. Li, X.-J., Onuferko, J. H., and Gates, B. C., J. Catal. 85, 176 (1984).

6. Schwank, J., Allard, L. F., Deeba, M., and Gates, B. C., J. Catal. 84, 27 (1983).

7. Deeba, M., Scott, J. P., Barth, R., and Gates, B. C., J. Catal. 71, 373 (1981).

8. Baek, K. H., PhD dissertation. University of Delware, in preparation.

9. Odebunmi, E. O., Zhao, Y., Knözinger, H., Tesche, B., Manogue, W. H., Gates, B. C., and Hulse, J., J. Catal. 86, 95 (1984).

10. Deeba, M., and Gates, B. C., J. Catal. 67, 303 (1981).

11. Treacy, M. M. J., and Howie, A., J. Catal. 63, 265 (1980).

12. Knözinger, H., and Zhao, Y., J. Catal. 71, 337 (1981).

13. Nicholls, J. N., Farrar, D. H., Jackson, P. F., Johnson, B. F. G., and Lewis, J., J. Chem. Soc. Dalton, 1395 (1982).

14. Krause, T., Davies, M. E., Lieto, J., and Gates, B. C., J. Catal. 94, 195 (1985).

15. Vannice, M. A., in "Catalysis: Science and Technology"' (J. R. Anderson and M. Boudart, Eds.), Vol. 3, p. 139. Springer-Verlag, Berlin, 1982; Nijs, H., and Jacobs, P. A., J. Catal. 65, 328 (1980); Kellner, C. S., and Bell. A. T., J. Catal. 75, 251 (1982); Jung, H.-J., and Vannice, M. A., J. Catal. 75, 410 (1982).

16. Dry, M. E., in "Catalysis: Science and Technology' (J. R. Anderson and M. Boudart, Eds.), Vol. 1, p. 159. Springer-Verlag, Berlin, 1981.

17. Van't Blik, H. F. J., van Zon, J. B. A. D., Huizinga, T., Vis, J. C., Koningsberger, D. C., and Prins, R., J. Phys. Chem. 87, 2264 (1983).

18. Driessen, J. M., Poels, E. K., Hindermann, J. P., and Ponec, V., J. Catal. 82, 26 (1983).

19. Watson, P. R., and Somorjai, G. A., J. Catal. 72, 347 (1981). 